ZOOLOGIA 27 (5): 718-724, October, 2010

doi: $10.1590 /$ S1984-46702010000500008

\title{
Abundance of epigaeic arthropods in a Brazilian savanna under different fire frequencies
}

\author{
Marcio Uehara-Prado1, 7; Ayr de M. Bello; Juliana de O. Fernandes;; \\ Adalberto J. Santos ${ }^{4}$; Igor A. Silva ${ }^{5} \&$ Marcus V. Cianciaruso ${ }^{6}$ \\ 1 Instituto Neotropical: Pesquisa e Conservação. Caixa Postal 19009, 81531-980 Curitiba, PR, Brazil. \\ E-mail: muprado@yahoo.com \\ ${ }^{2}$ Rua Marechal Mascarenhas de Moraes 191/902, 22030-040 Rio de Janeiro, RJ, Brazil. E-mail: ayrmbello@hotmail.com \\ ${ }^{3}$ Museu de Zoologia, Instituto de Biologia, Universidade Estadual de Campinas. Caixa Postal 6109, 13084-971 Campinas, \\ SP, Brazil.E-mail: juliana_olifer@yahoo.com.br \\ ${ }^{4}$ Departamento de Zoologia, Instituto de Ciências Biológicas, Universidade Federal de Minas Gerais. Avenida Antônio Carlos \\ 6627, 31270-901 Belo Horizonte, MG, Brazil. E-mail: oxyopes@yahoo.com \\ ${ }_{5}^{5}$ Departamento de Botânica, Centro de Ciências Biológicas e da Saúde, Universidade Federal de São Carlos. \\ Rodovia Washington Luiz, km 235, Caixa Postal 676, 13565-905 São Carlos, SP, Brazil. E-mail: igor6cordas@yahoo.com.br \\ ${ }^{6}$ Departamento de Ecologia, Instituto de Ciências Biológicas, Universidade Federal de Goiás. Caixa Postal 131, \\ 74001-970 Goiânia, GO, Brazil. E-mail: cianciaruso@gmail.com \\ 7 Corresponding author.
}

\begin{abstract}
Fire is a major determinant of structure and dynamics in savannas, and the rapid increase of human activities in this biome has changed the natural burning regime. The effects of fire on the fauna of the cerrado (Brazilian savanna) are still poorly understood, and studies comparing sites frequently and infrequently burned are scarce. In this study, the abundance of epigaeic arthropod orders and trophic guilds was assessed in cerrado sites located in the Brazilian Central Plateau that were subjected to three burning frequencies: frequent (HighFi), intermediary (MidFi), and infrequent (LowFi). In general, we found a positive relationship between the abundance of epigaeic arthropods and fire frequency. When arthropods were analyzed by orders, the abundance of Collembola and Orthoptera was lower in the LowFi site, while for Hemiptera, it was higher in the MidFi site. No significant differences were found for Hymenoptera, Coleoptera, and Araneae. The abundance of detritivores and herbivores decreased from HighFi to LowFi, but did not change significantly for omnivores and predators. These results indicate that some arthropod groups may not only be resilient to fire effects, but actually might benefit from fire effects in the cerrado. Characterizing arthropod responses to burning frequency at high taxonomic or functional levels is important for applied studies. Based on the results of the current study, springtails and ants seem to be particularly appropriate focal groups for further exploratory studies on the effects of fire at the species level.
\end{abstract}

KEY WORDS. Arachnida; burning; cerrado; Insecta; trophic guilds.

Originally covering around 2 million $\mathrm{km}^{2}$, the Brazilian cerrado is the largest savanna region in the Americas (GotTSberger \& Silberbauer-GotTsberger 2006). The fauna and flora of this region are the most diverse of the world's savannas (Mittermeier et al. 2004), comprising about 7,000 vascular plant species (CASTro et al. 1999) and an estimated 90,000 insect species (DIAS 1992). However, current threats to its biodiversity are daunting, because $70 \%$ of the region has already been converted into disturbed landscapes (MitTermeier et al. 2004).

Fire is a major natural disturbance in the cerrado that determines its structure and dynamics and influences vegetation physiognomy and plant composition (MOREIRA 2000), soil temperature (MIRANDA et al. 2002), and plant nutrient use efficiency (NARDOTO et al. 2006). Fire stimulates the resprouting, germination, flowering and fruiting of many fire-adapted plant species (Coutinho 1990, Miranda et al. 2002, Gottsberger \& Silberbauer-Gottsberger 2006), which may in turn foster animal populations that are directly or indirectly dependent on these resources. However, the rapid occupation of the cerrado region has increased the fire frequency to the point that fires are now the rule during the dry season, what has brought negative consequences for flora and fauna (Ramos-Neto \& Pivello 2000, MiRANDA et al. 2002). Frequent fires may harm animals and plants directly, by causing massive mortality, or indirectly, by changing local hydrology, nutrient availability, and soil properties (NeAry et al. 1999, Nardoto et al. 2006). For this reason, fire is becoming a threat to the biodiversity of the cerrado in many locations (Kuink \& Machado 2005, Durigan et al. 2007). 
Occupying various habitats and playing essential ecological roles in virtually every terrestrial ecosystem, arthropods are fundamental components of earth's biodiversity (WILSON 1987, York 1999, LAVelle et al. 2006). Arthropods play three broad ecological roles in tropical savannas: 1) they are particularly important drivers of soil properties and processes; 2) they regulate plant populations through herbivory, seed predation, and other direct interactions with plants; and 3) they are drivers of consumer food webs as competitors, predators, parasites, and prey (York 1999, ANDERSEn et al. 2003). Despite the great diversity and functional importance of savanna arthropods, they have received little attention by researchers working in the cerrado (see OliveIRA \& MARQUis 2004) and other tropical savannas (ANDERSEN et al. 2003). Of the few studies conducted in the cerrado so far, most have dealt with one or a few taxonomic groups and have reached different conclusions about fire effects (e.g., Morais \& Benson 1988, Prada et al. 1995, Seyffarth et al. 1996, Vieira et al. 1996, Marini-Filho 2000, Martins et al. 2004, Morais et al. 2007, Knoechelmann \& Morais 2008). Therefore, understanding the general responses of arthropods to different fire regimes remains a challenge.

This study investigated the abundance of epigaeic arthropod orders and trophic guilds under different fire frequencies in a cerrado reserve. Most of the epigaeic fauna uses the leaf litter layer, which provides a significant amount of fuel for wildfires in this ecosystem (Hoffmann 1996, Miranda et al. 2002). In addition, many orders of insects, such as Orthoptera, Hemiptera, Coleoptera, Lepidoptera, Hymenoptera, and Diptera, are important herbivores in savannas, especially those savannas on infertile soils and with few herbivore mammals (ANDERSEN et al. 2003). Because these characteristics apply to the Brazilian cerrado, we expect to find changes in arthropod abundance under different fire conditions. However, since many different responses to fire have been observed within and between arthropod orders (e.g., WarRen et al. 1987), we did not make predictions for specific taxonomic groups. Nevertheless, for trophic guilds, we expected that: 1) detritivore abundance should be negatively affected by fire due to the decrease in litter biomass (CHEN \& Wise 1999); 2) herbivore abundance should increase in frequently burned sites in response to plant regrowth (ANDERsen et al. 2003); 3) omnivore abundance should not be affected by fire due to their dietary flexibility; and 4) predator abundance should be positively affected by fire due to a general increase in prey abundance. Ultimately, this study provides information that may be useful to determine indicators of disturbance caused by fire in this cerrado reserve.

\section{MATERIAL AND METHODS}

This study was carried out in the Parque Nacional das Emas, a cerrado reserve located in the Brazilian Central Plateau ( $17^{\circ} 49^{\prime}$ $\left.18^{\circ} 28^{\prime} \mathrm{S}, 52^{\circ} 39^{\prime}-53^{\circ} 10^{\prime} \mathrm{W}\right)$. This park is one of the largest and best preserved cerrado reserves; it was included by UNESCO (2001) in the World Natural Heritage List as one of the sites containing the fauna, flora, and key habitats that characterize the cerrado (Ramos-Neto \& Pivello 2000, Batalha \& Martins 2002, Rodrigues et al. 2002, FrançA et al. 2007). The region has a humid tropical climate with wet summers and dry winters (Aw of Köppen 1948). The dry season extends from June to August and the wet season extends from September to May. Annual rainfall varies from 1200-2000 mm, concentrated from September to March, and mean annual temperature is $24.6^{\circ} \mathrm{C}$ (RAmos-Neto \& Pivello 2000). The topography is generally flat, and the altitude varies from 820 to 890 m (Ramos-Neto \& Pivello 2000).

The park area was used for cattle ranching in the past, and annual dry season burnings were used to promote pasture regrowth (Ramos-Neto \& Pivello 2000). Since the park delimitation in 1984, cattle are no longer allowed inside it and a fire exclusion policy has been established (Ramos-Neto \& Pivello 2000). As a consequence, uncontrolled wildfires have occurred every 3-4 years, burning on average $80 \%$ of the total area of the reserve each time they occur (Ramos-Neto \& Pivello 2000, França et al. 2007). Thus, since 1994, approximately $10 \mathrm{~km}^{2}$ of preventive firebreaks ( $30 \mathrm{~m}$ wide) are burned annually in the dry season to prevent the spread of eventual fires (FrançA et al. 2007).

In 1994, a lightning fire burned more than $90 \%$ of the Parque Nacional das Emas (Ramos-Neto \& Pivello 2000, FrançA et al. 2007). That year was considered "ground zero" for examining the effects of burning on arthropods in this study. Arthropods were sampled at three sites with different burning frequencies from 1994 to 2006: a firebreak burned annually (12 fire events since 1994, last burning in 2005), another firebreak burned five times in this period $(1996,1999,2001-2003)$, and a site unburned since 1994. Hereafter these sites will be referred as 'HighFi', 'MidFi', and 'LowFi', based on their burning frequency. This type of fire management has been undertaken every dry season when a fire brigade uses flamethrowers to burn all of the biomass within the firebreaks. Except for the firebreaks, no burning has occurred in adjacent areas since 2003. Because a true replication of burned areas was not possible within the study site, due to logistical, bureaucratic, and ethical reasons, a natural experiment approach was adopted with sampling being conducted at sites with a well-documented history of burning (see PARr \& CHOwn 2003). Additionally, the three sites were close enough to each other to reduce the probability of confounding factors (e.g., different land use in the past, soil type, and vegetation composition). Although this approach limits the degree of generalization from the findings and does not solve the statistical problem of a lack of true replicates for the fire treatments, it increases the likelihood that significant differences between sites are due to different fire frequencies (PUCHETA et al. 1998) allowing us to discuss the patterns found within the reserve.

In each of these sites, twenty pitfall traps were randomly placed at least $10 \mathrm{~m}$ apart from each other along $2.5 \mathrm{~km}$ transects (one per site). Pitfall traps were $500 \mathrm{ml}$ plastic cups leveled with the soil surface, with a $5.8 \mathrm{~cm}$ opening and 10.5 
$\mathrm{cm}$ depth, that were protected from direct rainfall by a circular polystyrene shield placed above them. Traps were filled with ca. $200 \mathrm{ml}$ of $30 \%$ propylene glycol, $0.1 \%$ formaldehyde, and a few drops of detergent. Pitfall traps were kept open from May 8 to May 12, 2006 at the end of the rainy season and the beginning of the dry season when herbaceous plant productivity is higher (Cianciaruso \& BatalHa 2009). All collected arthropods were preserved in $70 \%$ ethanol.

Arthropods were sorted to different taxonomic levels, from genera (e.g., ants and some Coleoptera) to order (e.g., Araneae and Scutigeromorpha). This sorting was necessary to place them into four coarse trophic categories: detritivores, herbivores, omnivores, and predators (based on MARINONI et al. 2001, Silvestre et al. 2003, Triplehorn \& Johnson 2005). Leafcutting ants were grouped with the herbivores. Ant abundance was based on the frequency of each species in the traps. Spider specimens were deposited in the collection of Instituto Butantan (São Paulo, Brazil), ants were deposited in the Museu de Zoologia, Universidade de São Paulo (São Paulo, Brazil), and the remaining taxa were deposited in the Museu de Zoologia, Universidade Estadual de Campinas (Campinas, Brazil).
Differences in the abundance of each order and trophic group among sites were analyzed using a one-way randomized analysis of variance, appropriate for unreplicated designs (PAYNE 2006). When significant differences were found, the Tukey posthoc test was applied.

\section{RESULTS}

A total of 1,192 individuals from eight arthropod orders were captured. Collembola was the most abundant order, representing 33\% of the arthropods in the sample, followed by Hymenoptera (mostly ants), Orthoptera, Hemiptera, Coleoptera, Araneae, Dyctioptera, and Scutigeromorpha (Tab. I). The most abundant trophic guild was the detritivores, made up of $38.5 \%$ of the individuals, followed by herbivores (27\%), omnivores (17.5\%), and predators (17\%). The abundance of trophic guilds was highly skewed by one or two taxonomic groups: $85 \%$ of the detritivores were Collembola, $69.3 \%$ of the herbivores were Orthoptera, $73.9 \%$ of predators were Hymenoptera and Araneae and $100 \%$ of the omnivores were Hymenoptera (exclusively ants) (Tab. I).

Table I. Abundance of epigaeic arthropod orders and trophic guilds in areas with different burning frequencies in the cerrado of Parque Nacional das Emas, Brazil.

\begin{tabular}{|c|c|c|c|c|c|}
\hline \multirow{2}{*}{ Taxa } & \multirow{2}{*}{ Trophic guild } & \multicolumn{3}{|c|}{ Burning rate ${ }^{1}$} & \multirow{2}{*}{ Total } \\
\hline & & HighFi & MidFi & LowFi & \\
\hline Araneae & Predators & 30 & 13 & 21 & 64 \\
\hline Collembola & Detritivores & 225 & 115 & 57 & 397 \\
\hline \multirow[t]{3}{*}{ Coleoptera $^{2}$} & Detritivores & 24 & 4 & 15 & 43 \\
\hline & Herbivores & 1 & 1 & 1 & 3 \\
\hline & Predators & 7 & 4 & 8 & 19 \\
\hline \multirow[t]{2}{*}{ Dictyoptera $^{3}$} & Detritivores & 3 & 9 & 11 & 23 \\
\hline & Predators & 0 & 1 & 0 & 1 \\
\hline \multirow[t]{2}{*}{ Hemiptera $^{4}$} & Herbivores & 30 & 28 & 14 & 72 \\
\hline & Predators & 8 & 19 & 6 & 33 \\
\hline \multirow[t]{3}{*}{ Hymenoptera $^{5}$} & Herbivores & 6 & 5 & 8 & 19 \\
\hline & Omnivores & 75 & 69 & 64 & 208 \\
\hline & Predators & 34 & 36 & 16 & 86 \\
\hline Orthoptera & Herbivores & 104 & 84 & 35 & 223 \\
\hline Scutigeromorpha & Predators & 0 & 1 & 0 & 1 \\
\hline \multicolumn{6}{|c|}{$\begin{array}{l}{ }^{1} \text { HighFi - site burned annually from } 1994 \text { to } 2006, \mathrm{MidFi} \text { - site burned five times in this period, LowFi - site unburned since } 1994 . \\
{ }^{2} \text { Detritivores include representatives of the families Nitidulidae, Scarabaeidae, Staphylinidae, and Tenebrionidae. Herbivores include } \\
\text { representatives of the families Brentidae, Chrysomelidae, and Tenebrionidae. Predators include representatives of the families Anthicidae, } \\
\text { Carabidae, Histeridae, and Staphylinidae. } \\
{ }^{3} \text { Detritivores include representatives of the orders Blattaria and Isoptera. Predators include representatives of the order Mantodea. } \\
{ }^{4} \text { Herbivores include representatives of the suborders Auchenorrhyncha and Heteroptera. Predators include representatives of the suborder } \\
\text { Heteroptera. } \\
5 \text { Herbivores include representatives of the family Formicidae (Attini). Omnivores include representatives of the family Formicidae } \\
\text { (Dolichoderinae, Formicinae, Myrmicinae). Predators include representatives of the families Formicidae (Ecitoninae, Myrmicinae, } \\
\text { Ponerinae, Pseudomyrmecinae) and Mutilidae. }\end{array}$} \\
\hline
\end{tabular}

ZOOLOGIA 27 (5): 718-724, October, 2010 
When arthropods were analyzed by order, the abundance of all but Hemiptera peaked in HighFi (Fig. 1). The abundance of Collembola was significantly higher in HighFi, whereas it did not differ between MidFi and LowFi. For Orthoptera, abundance was significantly lower in LowFi and did not differ between HighFi and MidFi. Hemiptera showed a significant difference only between MidFi and LowFi and was the only order in which abundance peaked in MidFi (Fig. 1). The abundance of Coleoptera was lower in MidFi and significantly different only between HighFi and MidFi. No significant differences were found for Araneae and Hymenoptera.

The abundance of all trophic guilds decreased from HighFi to LowFi (Fig. 2). Detritivore abundance was significantly higher in HighFi and did not differ between MidFi and LowFi. The abundance of herbivores was significantly higher in HighFi and MidFi when compared to LowFi. Omnivores and predators also showed a tendency to become less abundant with time since the last burning, yet this difference was not significant (Fig. 2).
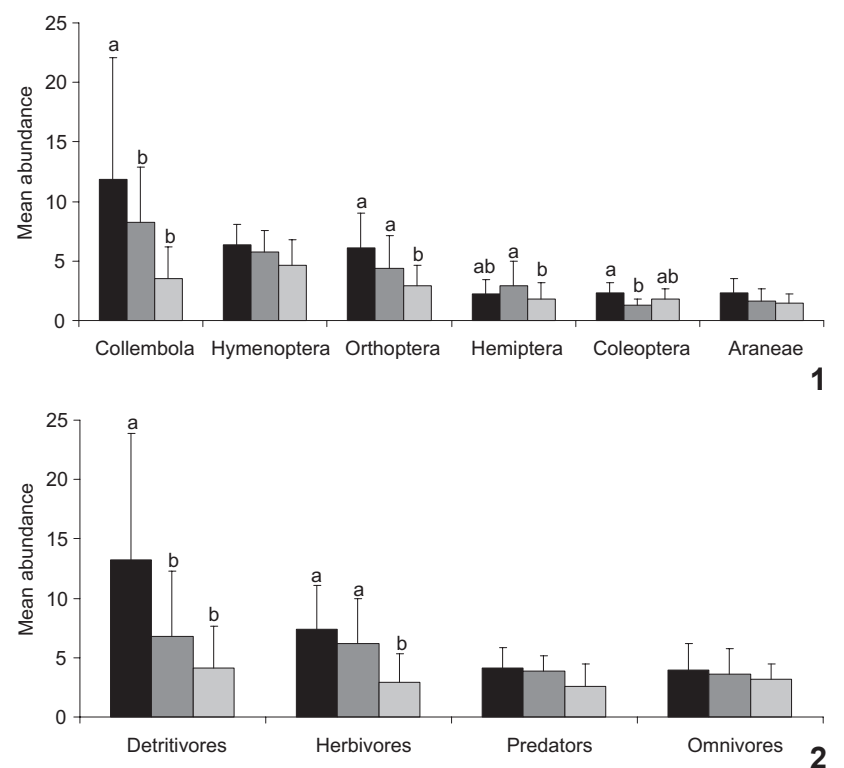

Figures 1-2. Mean abundance ( $\pm s d$ ) of arthropods in areas with different burning rates: HighFi (black bars), MidFi (dark gray bars), and LowFi (light gray bars). (1) Orders and (2) Trophic guilds. Different letters in the same sequence within an order or guild represent statistically significant differences in abundance (one-way randomized analysis of variance followed by a Tukey's post-hoc test, $p<0.05$ ).

\section{DISCUSSION}

The general tendency of finding a higher abundance of epigaeic arthropods with increased fire frequency corroborates some previous studies on the effects of fire on cerrado insects (e.g., Prada et al. 1995, Marini-Filho 2000, Knoechelmann \& Morais
2008). Our results show that these organisms are not only resilient to fire, as observed in other tropical savannas (ANDERSEN et al. 2003), but they are also able to take advantage of sites with different fire histories. Although we cannot establish any causal relationship, two general features may explain why fire seems to favor epigaeic arthropods. First, mortality due to fire should be low given the ability of many species to hide in natural cavities or to fly away from the fire front (ANDERSEN et al. 2003). Second, the amount of plant resources increases for a few months after a fire, with almost all herbaceous plants producing flowers or regrowing vigorously, allowing epigaeic arthropod species to take advantage of the nutrients released by fire (Coutinho 1990, Miranda et al. 2002). These available resources should attract many herbivore species, such as Orthoptera and Hemiptera, which benefit from the regrowth of plants (Chambers \& Samways 1998, Marini-Filho 2000, Andersen et al. 2003). In turn, an increase in the abundance of these species should attract their predators (CHEN \& Wise 1999). For example, PRADA et al. (1995) reported a nearly 20-fold increase in the number of flowering plants of an Asteraceae species in a burned site followed by a higher abundance of herbivorous insects. Also, ants visiting extrafloral nectaries were more frequent in cerrado sites burned biennially than in unburned sites (KNoechelmann \& Morais 2008).

A study carried out in the same period as the present study (Cianciaruso et al. 2010) showed that, despite the fact that the total aboveground biomass was higher in the LowFi site and lower in the HighFi site, when accounting only for living biomass, the HighFi site had about 50\% more biomass than the LowFi site. Moreover, a single grass species (Tristachya leiostachya Nees) was responsible for $68 \%$ of the total living biomass in the LowFi site whereas in both the HighFi and MidFi sites T. leiostachya, other grasses and woody species contributed more equally to total herbaceous aboveground biomass (Cianciaruso et al. 2010). Such monodominance in the LowFi site could be an alternative explanation for the patterns we found here for arthropods because it reduces the diversity of resources available in the LowFi site. Nonetheless, the relationship between burning frequency and epigaeic arthropod abundance does not appear to be so clear for all taxonomic or functional groups. Divergent responses to fire have been observed within and between arthropod orders in many savannas (e.g., WARRen et al. 1987, ANDERSEN et al. 2003).

The increase in detritivore abundance with higher burning frequency found in this study was unexpected because more detritivore individuals often occur in sites with an accumulation of organic matter (e.g., CHEN \& WISE 1999), such as unburned sites (OtTMar et al. 2001, Govender et al. 2006). On the other hand, the lower abundance of detritivores in the MidFi and LowFi sites may be explained by the dominance of Collembola in this trophic guild. Some dominant springtail species may be more abundant in burned than in unburned sites because they may use available shelters (stones and coarse woody debris) more ef- 
ficiently (BRAND 2002). An alternative explanation is, again, the dominance of T. leiostachya, which makes up a great part of the organic matter accumulated in the LowFi site (CiAnCIARUso et al. 2010) reducing the colonization by detritivores.

The abundance of omnivores did not differ among sites with different burning frequencies. The idiosyncratic nature of the omnivore guild in this study, composed exclusively of ants, may help us to understand their relationship with burning frequency. Almost $80 \%$ of the captures in this guild were composed of three dominant ant genera, Camponotus Mayr, 1861 (Formicinae), Pheidole Westwood, 1839 (Myrmicinae), and Linepithema Mayr, 1866 (Dolichoderinae) (data not shown), which exhibit very high recruitment and aggressive interspecific interactions even in disturbed sites (SiLvestre et al. 2003). These attributes allow these ant species to colonize open sites quickly and, coupled with their wide trophic niche, could be an explanation for the homogeneous response of omnivores to all burning frequencies. Morais \& Benson (1988) reported a high mortality of arboreal ants caused by fire, and a reduction in their abundance for at least 1.5 years after burning in a cerrado. They also postulated that ground ants would have higher survivorship after burning, due to a smaller effect of fire at the ground level. Their proposition was supported here at least for omnivorous ants. A study conducted in an Amazonian savanna found no effect of fire disturbance on species richness and a minor effect on species composition (VASCONCElos et al. 2008). PARR et al. (2004) also did not find a significant effect of burning on southern African savanna ant species richness or abundance, and commented on the resistance of ant assemblages to burning. However, these authors found significant differences in ant species composition between burned and unburned sites. Therefore, studies at the species level are needed to investigate whether there are shifts in the composition and species richness of ants in cerrado sites under different burning frequencies, even when their abundance does not change.

Differing responses of the arthropod orders that composed the predator guild homogenized the overall predator response (see Tab. I and Fig. 2), leading to the non-significant response in relation to fire frequency observed in this study. Spider abundance also did not differ significantly among sites, contrasting with a previous study that reported a significant reduction in spider abundance in a recently burned cerrado (GOMEs et al. 2007). However, in that study spiders were collected using Winkler extractors that selectively sample small spider species which could either be more susceptible to the effects of fire or slower in colonizing burned sites. On the other hand, the method used in the current study is more efficient for sampling ground active species (CHurchill 1993), which are the species that are most likely to colonize burned sites. Experimental evidence from agroecosystems has shown that active ground-dwelling spiders are efficient colonizers of new habitats, and are able to invade recently disturbed areas from both adjacent and distant habitat sources (e.g., HibBERT \& BUdDle 2008). Additionally, MARTins et al.
(2004) showed that the abundance of a sun spider (Solifugae) increased immediately after burning in a cerrado site, but this difference vanished 3-4 months later.

While long-term sampling and species-level identification are highly desirable in any assessment study, arthropod assessments to aid decision-making are often made under time and financial constraints (particularly in Brazil). Consequently, important decisions are usually based on snapshot samples with identifications made only at high taxonomic levels. In these unfavorable situations, the use of species abundance in higher taxonomic categories may be the only alternative (BRENNAN et al. 2006). Therefore, studies looking for consistent responses to fire at high taxonomic or functional levels are important in a practical way.

This study indicates that some cerrado arthropod groups are not only resilient to fire, as observed in Australian savannas (ANDERSEN et al. 2003), but also may actually benefit from burning. However, this conclusion should be considered an initial assessment of the responses to different fire regimes in cerrado arthropods at high taxonomic levels. Additional studies should be conducted in this ecosystem to confirm the generality of our results. Ultimately, the information provided here might be useful in the search for ecological indicators of disturbance by fire in cerrado. Springtails and ants seem to be particularly appropriate focal groups for further exploratory studies at the species level because they are abundant in samples and, in the case of ants, relatively well-known in the cerrado (see SilvesTre et al. 2003).

\section{ACKNOWLEDGEMENTS}

We acknowledge P. Loiola for fieldwork assistance and C. Matavelli, M. Magrini, and L. Kaminski for laboratory assistance. J. Barlow, A.V.L. Freitas, G. Machado, T.M. Lewinsohn, P.R. Guimarães Jr, and F.O. Roque made several suggestions in an early draft. The manuscript was improved by a number of helpful remarks from two anonymous referees. We are indebted to Instituto Brasileiro do Meio Ambiente (Ibama) for granting permission to work in Parque Nacional das Emas. M.V. Cianciaruso acknowledges Fundação de Amparo à Pesquisa do Estado de São Paulo (FAPESP, 04-15763-0) and I.A. Silva to Conselho Nacional de Desenvolvimento Científico e Tecnológico (CNPq, 141397/ 2006-3). A.J. Santos was financially supported by a FAPESP postdoctoral grant (03/04868-3) at Laboratório de Artrópodes, Instituto Butantan. This study was conducted as part of $\mathrm{M}$. Uehara-Prado's doctorate project in Ecology at Universidade Estadual de Campinas (CNPq scholarship 140116-2004-4).

\section{LITERATURE CITED}

Andersen, A.N.; J. Orgeas; R.D. Blanche \& L.M. Lowe. 2003. Terrestrial insects, p. 107-125. In: A.N. Andersen, G.D. Cook \& R.J. Williams (Eds). Fire in tropical savannas. Berlin, Springer-Verlag, 195p. 
Batalha, M.A. \& F.R. Martins. 2002. Life-form spectra of Brazilian cerrado sites. Flora 197 (6): 452-460. doi:10.1078/03672530-00062.

Brand, R.H. 2002. The effect of prescribed burning on epigeic springtails (Insecta: Collembola) of woodland litter. American Midland Naturalist 148 (2): 383-393. doi:10.1674/ 0003-0031(2002)148[0383:TEOPBO]2.0.CO;2.

Brennan, K.E.C.; L. Asby; J.D. Majer; M.L. Moir \& J.M. Кoch. 2006. Simplifying assessment of forest management practices for invertebrates: how effective are higher taxon and habitat surrogates for spiders following prescribed burning? Forest Ecology and Management 231 (1-3): 138-154. doi:10.1016/ j.foreco.2006.05.035.

Castro, A.A.J.F.; F.R. Martins; J.Y. Tamashiro \& G.J. Shepherd. 1999. How rich is the flora of Brazilian cerrados? Annals of the Missouri Botanical Garden 86 (1): 192-224.

Chambers, B.Q. \& M.J. Samways. 1998. Grasshopper response to a 40-year experimental burning and mowing regime, with recommendations for invertebrate conservation management. Biodiversity and Conservation 7 (8): 985-1012. doi:10.1023/A:1008803513740.

Chen, B. \& D.H. Wise. 1999. Bottom-up limitation of predaceous arthropods in a detritus-based terrestrial food web. Ecology 80 (3): 761-772. doi:10.1890/0012-9658(1999)080[0761: BULOPA]2.0.CO;2.

Churchill, T.B. 1993. Effects of sampling method on composition of a Tasmanian coastal heathland spider assemblage. Memmoirs of the Queensland Museum 33 (2): 475-481.

Cianciaruso, M.V. \& M.A. Batalha. 2009. Short-term community dynamics in seasonal and hyperseasonal cerrados. Brazilian Journal of Biology 69 (2): 631-637. doi:10.1590/S151969842009000200002.

Cianciaruso, M.V.; I.A. Silva \& M.A. Batalha. 2010. Above-ground biomass of functional groups in the herbaceous layer of savannas under different fire frequencies. Australian Journal of Botany 58: 169-174.

Coutinho, L.M. 1990. Fire in the Ecology of the Brazilian Cerrado, p. 82-105. In: J.G. GoldAMmer (Ed.). Fire in the tropical biota. Berlin, Springer-Verlag, 497p.

DiAs, B.F. DE S. 1992. Cerrados: Uma Caracterização, p. 11-25. In: B.F. DE S. DiAS (Ed.). Alternativas de desenvolvimento dos cerrados: manejo e conservação dos recursos naturais renováveis. Brasília, Funatura, 97p.

Durigan, G.; M.F. Siqueira \& G.A.D.C. Franco. 2007. Threats to the cerrado remnants of the State of São Paulo, Brazil. Scientia Agricola 64 (4): 355-363. doi:10.1590/S010390162007000400006.

França, H, M.B. Ramos-Neto \& A. Setzer. 2007. O fogo no Parque Nacional das Emas. Brasília, Instituto do Meio Ambiente e dos Recursos Naturais Renováveis, 140p.

Gomes, A.C.; M.F. Mineo \& H.L. Vasconcelos. 2007. Efeito do fogo na araneofauna de serapilheira do cerrado, p. 1-2. In: Anais do VIII Congresso de Ecologia do Brasil. Caxambu,
Sociedade de Ecologia do Brasil.

Gottsberger, G \& I. Silberbauer-Gottsberger. 2006. Life in the cerrado: a South American tropical seasonal vegetation. Origin, structure, dynamics and plant use. Ulm, Reta Verlag, vol. 1, 280p.

Govender, N.; W.S.W. Trollope \& B.W. Van Wilgen. 2006. The effect of fire season, fire frequency, rainfall and management on fire intensity in savanna vegetation in South Africa. Journal of Applied Ecology 23 (4): 748-758 doi:10.1111/ j.1365-2664.2006.01184.x.

Hibbert, A.C. \& C.M. Budde. 2008. Assessing the dispersal of spiders within agricultural fields and an adjacent mature forest. Journal of Arachnology 36 (1): 195-198. doi: 10.1636/T07-14SC.1.

Hoffmann, W.A. 1996. The effects of cover and fire on seedling establishment in a neotropical savanna. Journal of Ecology 84 (3): 383-393.

KLINK, C.A. \& R.B. Machado. 2005. Conservation of the Brazilian Cerrado. Conservation Biology 19 (3): 707-713. doi:10. 1111/j.1523-1739.2005.00702.x.

Knoechelmann, C.M. \& H.C. Morais. 2008. Visita de formigas (Hymenoptera: Formicidae) a nectários extra florais de Stryphnodendron adstringens (Mart.) Cov. (Fabaceae, Mimosoideae) em uma área de cerrado frequentemente queimado. Revista Brasileira de Zoociências 10 (1): 35-40.

Köppen, W. 1948. Climatologia. Mexico, Fondo Cultura Econômica, 388p.

Lavelle, P.; T. Decaëns; M. Aubert; S. Barot; M. Blouin; F. Bureau; P. Margerie; P. Mora \& J-P. Rossi. 2006. Soil invertebrates and ecosystem services. European Journal of Soil Biology 42 (S1): 3-15. doi:10.1016/j.ejsobi.2006.10.002.

Marini-Filho, O.J. 2000. Distance-limited recolonization of burned cerrado by leaf-miners and gallers in central Brazil. Environmental Entomology 29 (5): 901-906.

Marinoni, R.C.; N.G. Ganho; M.L. Monné \& J.R.M. Mermudes. 2001. Hábitos alimentares em Coleoptera (Insecta). Ribeirão Preto, Holos, 63p.

Martins, E.G.; V. Bonato; G. Machado; R. Pinto-da-Rocha \& L.S. Rocha. 2004. Description and ecology of a new species of sun spider (Arachnida: Solifugae) from the Brazilian Cerrado. Journal of Natural History 38 (18): 2361-2375. doi:10.1080/00222930310001647343.

Miranda, H.S.; M.C. Bustamante \& A.C. Miranda. 2002. The fire factor, p. 51-68. In: P.S Oliveira \& R.J. Marquis (Eds). The Cerrados of Brazil: Ecology and Natural History of a Neotropical Savanna. New York, Columbia University Press, 424p.

Mittermeier, R.A.; P.R. Gil; M. Hoffmann; J. Pilgrim; T. Brooks; C.G. Mittermeier; J. Lamoreux \& G.A.B. Da Fonseca. 2004. Hotspots Revisited: Earth's Biologically Richest and Most Endangered Ecoregions. Mexico, CEMEX, 392p.

Morais, H.C. \& W.W. Benson. 1988. Recolonização de vegetação de cerrado após queimada por formigas arborícolas. Revista Brasileira de Biologia 48 (3): 459-466. 
Morais, H.C.; B.C. Cabral; J.A. Mangabeira \& I.R. Diniz. 2007. Stenoma cathosiota Meyrick (Lepidoptera: Elachistidae) in the Cerrado of Brasilia: temporal and spatial variation of caterpillar abundance. Neotropical Entomology 36 (6): 843847. doi:10.1590/S1519-566X2007000600004.

Moreira, A.G. 2000. Effects of fire protection on savanna structure in Central Brazil. Journal of Biogeography 27 (4): 1021-1029. doi:10.1111/j.1365-2699.2000.00422.x.

Nardoto, G.B.; M.M.C. Bustamante; A.S. Pinto \& C.A. Klink. 2006. Nutrient use efficiency at ecosystem and species level in savanna areas of Central Brazil and impacts of fire. Journal of Tropical Ecology 22 (2): 191-201. doi:10.1017/ S0266467405002865.

Neary, D.G.; C.C. Klopatek; L.F. DeBano \& P.F. Ffolliott. 1999. Fire effects on belowground sustainability - a review and synthesis. Forest Ecology and Management 122 (1): 5171. doi:10.1016/S0378-1127(99)00032-8.

Oliveira, P.S. \& R.J. Marquis. 2004. Introduction: Development of research in the cerrados, p. 1-10. In: P.S. Oliveira \& R.J. MARQuis (Eds). The Cerrados of Brazil: Ecology and Natural History of a Neotropical Savanna. New York, Columbia University Press, 424p.

OtTMar, R.D.; R.E. VihnaneK; H.S. Miranda; M.N. Sato \& S.M.A. ANDRADE. 2001. Stereo photo series for quantifying Cerrado fuels in central Brazil - Volume I. U.S. Department of Agriculture, Forest Service, Pacific Northwest Research Station, 87p.

PARR, C.L. \& S.L. Chown. 2003. Burning issues for conservation: a critique of faunal fire research in Southern Africa. Austral Ecology 28 (4): 384-395. doi:10.1046/j.1442-9993.2003. 01296.x.

Parr, C.L.; H.G. Robertson; H.C. Biggs \& S.L. Chown. 2004. Response of African savanna ants to long-term fire regimes. Journal of Applied Ecology 41 (4), 630-642. doi:10.1111/ j.0021-8901.2004.00920.x.

PaYNe, R.W. 2006. New and traditional methods for the analysis of unreplicated experiments. Crop Science 46: 2476-2481. http://dx.doi.org/10.2135/cropsci2006.04.0273.

Prada, M.; O.J. Marini-Filho \& P.W. Price. 1995. Insects in flower heads of Aspilia foliacea (Asteraceae) after a fire in a central Brazilian savanna: evidence for the vigor hypothesis. Biotropica 27 (4): 513-518.

Pucheta, E.; M. Cabido; S. Díaz \& G. Funes. 1998. Floristic composition, biomass, and aboveground net plant production in grazed and protected sites in a mountain grassland of central Argentina. aActa Oecologica 19 (2): 97-105. doi:10.1016/ S1146-609X(98)80013-1
Ramos-Neto, M.B. \& V.R. Pivello. 2000. Lightning fires in a Brazilian savanna National Park: rethinking management strategies. Environmental Management 26 (6): 675-684. doi:10.1007/s002670010124.

Rodrigues, F.H.G.; L. Silveira; A.T. Jacomo; A.P. Carmignotto; A.M.R. Bezerra; D. Coelho, H.Garbogini; J. Pagnozzi \& A. Hass. 2002. Composição e caracterização da fauna de mamíferos do Parque Nacional das Emas, Goiás. Revista Brasileira de Zoologia 19 (2): 589-600.

Seyffarth, J.A.S.; A.M. Calouro \& P.W. Price. 1996: Leaf rollers in Ouratea hexasperma (Ochnaceae): fire effect and the plant vigor hypothesis. Revista Brasileira de Biologia 56 (1): 13537.

Silvestre, R.; C.R.F. Brandão \& R.R. Silva. 2003. Grupos funcionales de hormigas: El caso de los gremios del Cerrado, Brasil, p. 113-143. In: F. FERNÁNDEZ (Ed.). Introducción a las Hormigas de la Región Neotropical. Bogotá, Instituto de Investigación de Recursos Biológicos Alexander Von Humboldt, 398p.

Triplehorn, C.A. \& N.F. Johnson. 2005. Borror and DeLong's Introduction to the Study of Insects. Belmont, Thomson Brooks/Cole, $7^{\text {th }}$ ed., $864 \mathrm{p}$.

UnESCO. 2001. Cerrado protected areas: Chapada dos Veadeiros and Emas National Parks. United Nations Educational, Scientific, and Cultural Organization. Available online at: http://whc.unesco.org/en/list/1035 [Accessed: 15.X.2010]

Vasconcelos, H.L.; M.F. Leite; J.M.S. Vilhena; A.P. Lima \& W.E. Magnusson. 2008. Ant diversity in an Amazonian savanna: relationship with vegetation structure, disturbance by fire, and dominant ants. Austral Ecology 33 (2): 221-231. doi:10.1111/j.1442-9993.2007.01811.x.

Vieira, E.M.; I. Andrade \& P.W. Price. 1996: Fire effects on a Palicourea rigida (Rubiaceae) gall midge $-\mathrm{a}$ test of the plant vigor hypothesis. Biotropica 28 (2): 210-217.

WarRen, S.D.; C.J. Scifres \& P.D. Teel. 1987. Response of grassland arthropods to burning - a review. Agriculture, Ecosystems and Environment 19 (2): 105-130. doi:10.1016/01678809(87)90012-0.

Wilson, E.O. 1987. The little things that run the world. Conservation Biology 1 (4): 344-346. doi:10.1111/j.15231739.1987.tb00055.x.

YoRK, A. 1999. Long-term effects of frequent low-intensity burning on the abundance of litter-dwelling invertebrates in coastal blackbutt forests of southeastern Australia. Journal of Insect Conservation 3 (3): 191-199. doi:10.1023/ A:1009643627781.

Submitted: 04.XI.2009; Accepted: 27.VIII.2010.

Editorial responsibility: Glauco Machado 